\title{
Kolaborasi praktek kesehatan interprofessional dalam asuhan ibu hamil dengan diabetes mellitus: sebuah scoping review
}

\section{The collaborative practices of interprofessional health in the caring of pregnant women with diabetes mellitus: a scoping review}

\author{
Resda Pebriani $^{1 *}$, Sulistyaningsih ${ }^{2}$ \\ ${ }^{1,2}$ University of 'Aisyiyah Yogyakarta. West Ringroad Street No.63, Sleman 55592, Indonesia \\ ${ }^{1}$ pebrianiresda24@gmail.com*; ${ }^{2}$ sulistyaningsih@unisayogya.ac.id \\ Tanggal Submisi: 24 Maret 2021, Tanggal Penerimaan: 16 April 2021
}

\begin{abstract}
Abstrak
Masih tingginya prevelensi diabetes melitus pada ibu hamil mempengaruhi ibu dan keturunannya, dan merupakan masalah kesehatan masyarakat yang terus meningkat. Dengan adanya pelaksanaan interprofesional colaboration dalam gestasional diabetes mellitus pada ibu hamil dapat menjadi upaya yang efektif dan komprehensif untuk menurunkan angka kejadian gestasional diabetes mellitus pada ibu hamil.Tujuan: Mengetahui peran dan hambatan praktik kolaborasi dalam kesehatan pada kehamilan diabetes melitus. Metode: Pencarian sistematis dalam database pubmed, proquest, Ebsco, Sciene Direct dan Googles cholar mendapatkan 1031 artikel. Mengikuti kriteria inklusi, 7 (Tujuh) artikel memenuhi syarat dan Mengikuti kerangka kerja Arksey dan O'Malley. Hasil: Analisis tematik digunakan untuk mengidentifikasi konsepkonsep inti. Penulis mengelompokkan konsep inti ini kedalam dua tema yaitu peran tenaga kesehatan dan hambatan dalam praktik kolaborasi kesehatan pada asuhan ibu hamil dengan diabetes militus. Kesimpulan: Peran tenaga kesehatan dalam memberikan asuhan pada ibu hamil dengan diabetes melitus sangat berpengaruh dalam praktik kolaborasi dalam menurunkan prevalensi diabetes militus pada ibu hamil.
\end{abstract}

Kata kunci: diabetes melitus, hambatan, ibu hamil, interprofesional kolaborasi, peran,

\begin{abstract}
The prevalence of diabetes mellitus in pregnant women is still increasing, which affects the mother and her offspring and is a public health problem. With the implementation of interprofessional collaboration in gestational diabetes mellitus in pregnant women, it can be an effective and comprehensive effort to reduce the incidence of gestational diabetes in pregnant women. Methods: Systematic search in pubmed, proquest, Ebsco, Sciene Direct and Googles cholar databases found 1031 articles. Following the inclusion criteria, 7 (Seven) articles were eligible and Following the Arksey and O'Malley framework. Results: Thematic analysis was used to identify the core concepts. The author groups this core concept into two themes, namely the role of health workers and obstacles in the practice of health collaboration in the care of pregnant women with diabetes mellitus. Conclusion: The role of health workers in providing care to pregnant women with diabetes mellitus is very influential in collaborative practice in reducing the prevalence of diabetes mellitus in pregnant women.
\end{abstract}

Keywords: barriers, diabetes mellitus, interprofessional collaboration, pregnant women, roles 


\section{INTRODUCTION}

Gestational diabetes mellitus (GDM) is hyperglycemia that is first identified during pregnancy and it increases the risk of adverse perinatal results. The increase of prevalence of gestational diabetes mellitus (GDM) affects mothers and their infant, and is public health problem which continues to increses Muche et al., (2020). In accordance with Rahayu \& Chen., (2020) diabetes sufferers have increased rapidly around the worldwide. Indonesia is estimated to have the eighth largest population of diabetics in 2045 , with a country of 10.7 million people with diabetes. Further, in 2019 it is calculated to be 13.7 million in 2030 and 16.6 million in 2045.

Optimal collaborative practice will reduce complications, conflict between health teams, and reduce mortality. From a psychological health perspective, collaborative practice can improve patient satisfaction such as reducing treatment duration, reducing medical costs, reducing suicide incidents, and reducing outpatient incidents. Direct interaction between health workers and patients that takes place continuously and in collaboration with other health workers is very necessary for the creation of interprofessional cooperation (Kurniasih et al., 2019)

Implementation of interprofessional collaboration in gestational diabetes mellitus, health workers who play a role in it, namely general practitioners, midwives, nurses, nutritionists. Barriers that arise in the implementation of interprofessional collaboration in gestational diabetes mellitus depend on individual of health workers and the unstructured system (Wieser et al., 2020)

Interprofessional collaboration in gestational diabetes mellitus (GDM) in pregnant women does not yet exist, thus, the further scoping review is needed. To find out about the roles and barriers of health professionals in the practice of interprofessional health collaboration in the case of gestational diabetes mellitus (GDM).

\section{RESEARCH METHODS}

\section{Research Design}

Following the Arksey and O'Malley framework. The stages carried out in the scoping review, it consisted of 5 stages: 1: Identifying the research question. $2:$ Identifying relevant studies. 3 : The selection of study. 4 : Creating a data chart. 5 : Compiling, summarizing and reporting the results (Arksey \& O’Malley, 2005).

\section{Inclusion and Exclusion Criteria}

the selecting the relevant articles, the researchers determined the inclusion criteria, namely English-language publications from 2010 to 2020, articles that discuss the role, constraints, forms of midwife cooperation in pregnant women with diabetes mellitus.

The exclusion criteria of this article were opinion articles / reports / discussions, review articles, publication papers, non-full text articles, and manuscript / thesis /undergraduate thesis / KTI articles.

\section{Article Extraction}

This Scooping Review has identified a literature study. The design of framework was used as a basis for determining inclusion and exclusion criteria so that the data sought did not widen and it focused on the context being sought. Search strategy and specific keywords used in the search process. Keywords used were $((()((()($ interprofessional collaboration *) OR multidisciplinary *) OR interprofessional teamwork *) AND midwifery) OR midwives) OR midwife) AND pragnancy) OR pregnant) AND diabetes mellitus type 2 OR diabetes mellitus OR diabetes type 2). Article selection used the inclusion and exclusion criteria through PRISMA flowchart as many as 1,031 articles and 7 articles that have been matched, then 
conducting critical appraisal using JBI (Joanna Briggs Institute) from 7 articles obtained. Further, charting was conducted, as well as compiling, summarizing and reporting results.

\section{Prisma flowchart}

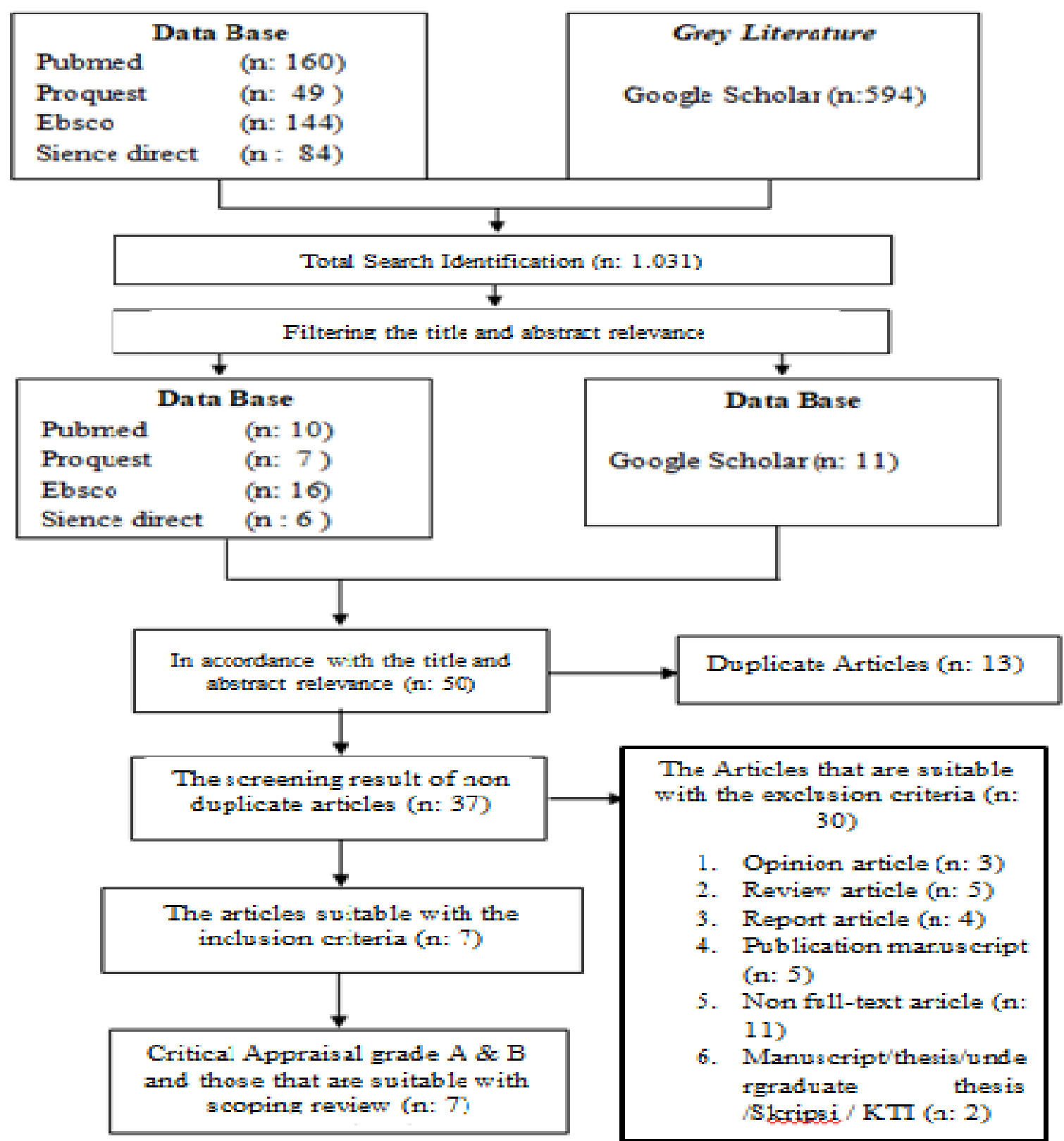

Figure 1. Search flow for collaborative practices of interprofessional health in the caring of pregnant women with diabetes mellitus.

\section{RESULT AND DISCUSSION}

From result the role of collaboration of health interprofessional in pregnant women with diabetes mellitus. From 7 articles, it was found that the role of collaborative practice of interprofessional health in the gestational diabetes mellitus consisted of obstetricians, 
midwives, nurses, nutritionists and diabetes specialists, where they had their respective roles in diabetes mellitus pregnancy.

Obstetrician. The role of an obstetrician is diagnosis counseling. The results of the research by Kunath et al., (2019) assert that the role of obstetricians is to provide counseling on a balanced diet lifestyle. The results of research by Taylor et al., (2017) argue that the obstetrician checks and diagnoses after it refers to the hospital.

Midwife. The role of a midwife is counseling and early management of diabetes mellitus pregnancy. The results of research by Meloncelli et al., (2019) explain that midwife controls body weight and blood glucose. The results of research by Alayoub et al., (2018) state that midwives play an important role in providing education to increase knowledge about gestational diabetes mellitus (GDM). The results of the research by Kunath et al., (2019) point out that the role of midwife is to provide counseling on a balanced diet lifestyle.

Nutritionist. The role of a nutritionist is the education related to nutrition. The results of the study by Meloncelli et al., (2019) emphasize more on nutritional therapy to control normal blood glucose. Research results by Alayoub et al., (2018) explain that it is important to provide education to increase knowledge about gestational diabetes mellitus (GDM).

Barriers to collaborative practice of Interprofessional Health in Pregnant Women with Diabetes Miletus. Several articles were found regarding the obstacles to the practice of interprofessional health cooperation in pregnant women with diabetes mellitus, namely the lack of awareness, communication and workshops for health workers. The results of research by Taylor et al., (2017) point out that the obstacle is the need for attention and support from health workers on the care of Gestational diabetes mellitus (GDM).

The results of the study by Simmons et al., (2018) which assert that inhibition is due to negligence of medical personnel, this delay is a risk in the first trimester treatment of gestational diabetes mellitus (GDM). The results of research by Kirkham et al., (2017) state that inhibiting care and opportunities for improved communication, networks are strengthened through educational workshops and related Partnership activities (it covers the quality assurance clinical enrollment activities).

Table 1. Collaborative Practice of Health Interprofessional on the Pregnancy Service of Diabetes Mellitus

\begin{tabular}{|c|c|c|c|c|}
\hline Articles & $\begin{array}{c}\text { Health } \\
\text { Interprofessionals }\end{array}$ & Quote & Theme & Sub Themes \\
\hline $\begin{array}{l}\text { Meloncelli et } \\
\text { al., (2019) }\end{array}$ & Nutritionists & $\begin{array}{l}\text { "The role of a } \\
\text { nutritionist is to } \\
\text { regulate } \\
\text { recommended diet } \\
\text { and exercise } \\
\text { habits." }\end{array}$ & $\begin{array}{l}\text { The role of } \\
\text { interprofessional } \\
\text { health workers in } \\
\text { pregnancy with } \\
\text { diabetes mellitus. }\end{array}$ & Counseling \\
\hline $\begin{array}{l}\text { Alayoub et al., } \\
\text { (2018) }\end{array}$ & Midwife & $\begin{array}{l}\text { "Midwife } \\
\text { demonstrates that } \\
\text { the education } \\
\text { sessions } \\
\text { effective are } \\
\text { demonstrating the } \\
\text { knowledge that } \\
\text { gained is consistent } \\
\text { in all groups." }\end{array}$ & $\begin{array}{l}\text { The role of } \\
\text { interprofessional } \\
\text { health workers in } \\
\text { pregnancy with } \\
\text { diabetes mellitus }\end{array}$ & $\begin{array}{l}\text { Educational } \\
\text { Intervention }\end{array}$ \\
\hline $\begin{array}{l}\text { Taylor et al., } \\
\text { (2017) }\end{array}$ & Obstetricians & $\begin{array}{l}\text { "Obstetricians } \\
\text { conduct a survey in }\end{array}$ & $\begin{array}{l}\text { The role of } \\
\text { interprofessional }\end{array}$ & Interview Survey \\
\hline
\end{tabular}




\begin{tabular}{|c|c|c|c|c|}
\hline Articles & $\begin{array}{c}\text { Health } \\
\text { Interprofessionals }\end{array}$ & Quote & Theme & Sub Themes \\
\hline & & $\begin{array}{l}\text { several clinics to } \\
\text { find out gestational } \\
\text { diabetes mellitus } \\
\text { that should be } \\
\text { referred" }\end{array}$ & $\begin{array}{l}\text { health workers in } \\
\text { pregnancy with } \\
\text { diabetes mellitus. }\end{array}$ & \\
\hline $\begin{array}{l}\text { Kunath et al., } \\
\text { (2019) }\end{array}$ & Midwife & $\begin{array}{l}\text { "Midwife provides } \\
\text { lifestyle counseling } \\
\text { which includes a } \\
\text { balanced healthy } \\
\text { diet, regular } \\
\text { physical activity } \\
\text { and monitor weight } \\
\text { gain" }\end{array}$ & $\begin{array}{l}\text { The role of } \\
\text { interprofessional } \\
\text { health workers in } \\
\text { pregnancy with } \\
\text { diabetes mellitus }\end{array}$ & Counseling \\
\hline $\begin{array}{c}\text { Simmons et al., } \\
\text { (2018) }\end{array}$ & Obstetricians & $\begin{array}{l}\text { "Obstetricians test } \\
\text { for risk factors in } \\
\text { early pregnancy } \\
\text { diabetes mellitus } \\
\text { with an oral glucose } \\
\text { test" }\end{array}$ & $\begin{array}{l}\text { The role of } \\
\text { interprofessional } \\
\text { health workers in } \\
\text { pregnancy with } \\
\text { diabetes mellitus }\end{array}$ & Screening \\
\hline $\begin{array}{l}\text { Egan et al., } \\
\text { (2017) }\end{array}$ & Obstetricians & $\begin{array}{l}\text { "Obstetricians } \\
\text { evaluate the } \\
\text { effectiveness of } \\
\text { prenatal care for } \\
\text { women with } \\
\text { pregestational } \\
\text { diabetes mellitus." }\end{array}$ & $\begin{array}{l}\text { The role of } \\
\text { interprofessional } \\
\text { health workers in } \\
\text { pregnancy with } \\
\text { diabetes mellitus }\end{array}$ & Questionnaire \\
\hline $\begin{array}{l}\text { Kirkham et al., } \\
\text { (2017) }\end{array}$ & Obstetricians & $\begin{array}{l}\text { "Obstetricians } \\
\text { support the } \\
\text { implementation of } \\
\text { the evidence gap in } \\
\text { practice. This } \\
\text { includes promoting } \\
\text { early testing of } \\
\text { women, integration } \\
\text { of primary and } \\
\text { tertiary care, linking } \\
\text { antenatal and } \\
\text { diabetes." }\end{array}$ & $\begin{array}{l}\text { The role of } \\
\text { interprofessional } \\
\text { health workers in } \\
\text { pregnancy with } \\
\text { diabetes mellitus. }\end{array}$ & Education \\
\hline
\end{tabular}

From discussion the 7 articles, 2 themes were found, namely the role and barriers to collaborative practice of Interprofessional Health in Pregnant Women with Diabetes Mellitus. The role of interprofessional health collaborative practices in pregnant women with diabetes mellitus consists of obstetricians, midwives, nutritionists, where they have their respective roles in the pregnancy service of diabetes mellitus and the barriers in the collaborative practice of interprofessional health on the pregnancy service of diabetes mellitus including the lack of awareness of health workers, lack of clinical administration accuracy, lack of communication of medical personnel and workshops of education.

a. The role of collaborative practice of interprofessional health in the gestational diabetes mellitus.

1) Obstetrician

The role of obstetricians in the research results of Taylor et al., (2017) that obstetricians examine and diagnose after referring to the hospital. The results of the study Kunath et al., (2019) assert that the role of obstetricians in lifestyle counseling 
which includes a balanced diet does not result the significant reduction in pregnant women who are overweight during pregnancy.

2) Midwife

The role of midwife in research results Meloncelli et al., (2019) regarding to health professionals who are responsible for tasks such as medical nutrition therapy, the weight of pregnancy and self-blood glucose in educational monitoring, officers who play a role in all members of the multidisciplinary Gestational diabetes mellitus team (GDM). The results of research by Alayoub et al., (2018) assert that midwife plays an important role in providing education to increase knowledge about gestational diabetes mellitus (GDM). The results of the study Kunath et al., (2019) state that the role of midwives in lifestyle counseling which includes a balanced diet does not result in a significant reduction in pregnant women who are overweight during pregnancy.

3) Nutritionist

The results of research by Meloncelli et al., (2019) point out that health professionals are nutritionists. Regarding health professionals who are responsible for tasks such as medical nutrition therapy. The results of research by Alayoub et al., (2018) state that nutritionists play an important role in providing education to increase knowledge about gestational diabetes mellitus (GDM).

b. Barriers to collaborative practice of interprofessional health in the gestational diabetes mellitus.

In providing services to pregnant women with diabetes mellitus, including the lack of awareness of health workers, lack of communication by medical personnel and educational workshops.

According to Timmermans et al., (2019) that when discussing the barriers to women's lack of interest in pregnancy with diabetes mellitus indicates that very few women with diabetes mellitus receive preconception care. It is due to the lack of information from health professionals about diabetes mellitus in pregnancy.

The results of the study by Nielsen et al., (2012)The barriers to increase the maternal health associated with GDM are identified, including the lack of trained health care providers, especially obstetricians. Due to the lack of a referral system and long distances to health facilities, a lack of concern about women's health, because they feel healthy or they have less time for self-care, due to the demands of the baby or other responsibilities as a barrier to the management of GDM or the further action on the postpartum.

It is not surprising that Irish women have good education generally. The barrier that the researcher encountered is language because English is not their first language, cultural barriers such as beliefs, norms and traditions may also have an impact on the answer of non-Buddhist. Life and lifestyle vary greatly from agriculture to other cultures, due to the fact that the questionnaire concentrated heavily on diet, their answers might be influenced by their norms and traditions (Alayoub et al., 2018)

Research results Mersereau et al., (2011) indicates that the biggest barriers to glycemic control for women are lack of knowledge, lack of access, and attitudes. By educating women with diabetes about the importance of knowledge, the importance of access, and attitudes. Women with diabetes mellitus can know the importance of using effective birth control until they have achieved good glycemic control so then it can help reduce the risk of adverse pregnancy. 
According to the results of research in Indonesia, Suryani et al., (2013) The obstacle encountered is lack of adherence to diet, which is the change in behavior by obeying the regulations regarding to health restoration. The level of adherence is measured using the Adherence scale. The higher of the total score obtained, the higher level of compliance the subject has. Supported by research by Hui et al., (2014) found constraints such as lack of adherence to a balanced diet. The role of midwives and nutritionists is to provide support, education, and manage a healthy diet for pregnant women with diabetes mellitus.

\section{LIMITATION}

This scoping review used a systematic approach to identify the article related to the role. It was merely undertaken in PubMed, ProQuest, Ebsco, Sciene Direct and Google scholar by using a relatively narrow search algorithm. A broader search can lead to the identification of the following article. Notwithstanding the foregoing, we aimed to extract the roles and barriers described in this article to provide an overview of the topic. Another main benefit was the process of summarizing the appropriate roles of the respective healthcare profession.

\section{CONCLUSION}

The role of collaborative practice of interprofessional health in the gestational with diabetes mellitus. The obstetrician provided counseling, information, support, care, education, and conducted collaboration with other medical personnel. Midwife provided care, education, collaboration, respected the patients, maintained the privacy, provided counseling, created the schedule of consultations and provided support. Nutritionists provided education, and counseling about diet.

Barriers on the collaborative practice of interprofessional health in the gestational with diabetes mellitus. Apart from the role of collaborative practice of interprofessional health, it found that the barriers occurred in the services that provided for gestational with diabetes mellitus, namely the lack of awareness of health workers, lack of communication of medical personnel and educational workshops.

\section{REFERENCE}

Alayoub, H., Curran, S., Coffey, M., Hatunic, M., \& Higgins, M. (2018). Assessment of the effectiveness of group education on knowledge for women with newly diagnosed gestational diabetes. Irish Journal of Medical Science (1971 -), 187(1), 65-68. https://doi.org/10.1007/s11845-017-1609-9

Arksey, H., \& O’Malley, L. (2005). Scoping studies: Towards a methodological framework. International Journal of Social Research Methodology: Theory and Practice, 8(1), 19-32. https://doi.org/10.1080/1364557032000119616

Egan, A. M., Galjaard, S., Maresh, M. J. A., Loeken, M. R., Napoli, A., Anastasiou, E., Noctor, E., de Valk, H. W., van Poppel, M., Todd, M., Smith, V., Devane, D., \& Dunne, F. P. (2017). A core outcome set for studies evaluating the effectiveness of prepregnancy care for women with pregestational diabetes. Diabetologia, 60(7), 1190-1196. https://doi.org/10.1007/s00125-017-4277-4

Hui, A. L., Sevenhuysen, G., Harvey, D., \& Salamon, E. (2014). Barriers and coping strategies of women with gestational diabetes to follow dietary advice. Women and Birth, 27(4), 292-297. https://doi.org/10.1016/j.wombi.2014.07.001 
Kirkham, R., Boyle, J. A., Whitbread, C., Dowden, M., Connors, C., Corpus, S., McCarthy, L., Oats, J., McIntyre, H. D., Moore, E., O’Dea, K., Brown, A., \& Maple-Brown, L. (2017). Health service changes to address diabetes in pregnancy in a complex setting: Perspectives of health professionals. BMC Health Services Research, 17(1), 1-12. https://doi.org/10.1186/s12913-017-2478-7

Kunath, J., Günther, J., Rauh, K., Hoffmann, J., Stecher, L., Rosenfeld, E., Kick, L., Ulm, K., \& Hauner, H. (2019). Effects of a lifestyle intervention during pregnancy to prevent excessive gestational weight gain in routine care - the cluster-randomised GeliS trial. BMC Medicine, 17(1), 5. https://doi.org/10.1186/s12916-018-1235-z

Kurniasih, Y., Sari, R. K., \& Santosa, A. (2019). Interprofessional collaboration meningkatkan pelaksanaan sasaran keselamatan pasien. Journal of Health Studies, 3(2), 113-120. https://doi.org/10.31101/jhes.883

Meloncelli, N., Barnett, A., Pelly, F., \& de Jersey, S. (2019). Diagnosis and management practices for gestational diabetes mellitus in Australia: Cross-sectional survey of the multidisciplinary team. Australian and New Zealand Journal of Obstetrics and Gynaecology, 59(2), 208-214. https://doi.org/10.1111/ajo.12816

Mersereau, P., Williams, J., Collier, S. A., Mulholland, C., Turay, K., \& Prue, C. (2011). Barriers to managing diabetes during pregnancy: The perceptions of health care practitioners. Birth, 38(2), 142-149. https://doi.org/10.1111/j.1523-536X.2010.00464.x

Muche, A. A., Olayemi, O. O., \& Gete, Y. K. (2020). Gestational diabetes mellitus increased the risk of adverse neonatal outcomes: A prospective cohort study in Northwest Ethiopia. Midwifery, 87. https://doi.org/10.1016/j.midw.2020.102713

Nielsen, K. K., De Courten, M., \& Kapur, A. (2012). Health system and societal barriers for gestational diabetes mellitus (GDM) services - Lessons from World Diabetes Foundation supported GDM projects. BMC International Health and Human Rights, 12(1). https://doi.org/10.1186/1472-698X-12-33

Rahayu, H. T., \& Chen, C. M. (2020). Psychometric Testing of an Indonesian-Version Diabetes Self-Management Instrument. Journal of Nursing Research, 28(6). https://doi.org/10.1097/jnr.0000000000000403

Simmons, D., Nema, J., Parton, C., Vizza, L., Robertson, A., Rajagopal, R., Ussher, J., \& Perz, J. (2018). The treatment of booking gestational diabetes mellitus (TOBOGM) pilot randomised controlled trial. BMC Pregnancy and Childbirth, 18(1), 151. https://doi.org/10.1186/s12884-018-1809-y

Suryani, N. ., Wirasuta, I. M. A. ., \& Susanti, N. M. . (2013). Pengaruh Konseling Obat dalam Home Care Terhadap Kepatuhan Pasien Diabetes Melitus Tipe 2 dengan Komplikasi Hipertensi. Jurnal Farmasi Udayana, 6-12.

Taylor, C., McCance, D. R., Chappell, L., Nelson-Piercy, C., Thorne, S. A., Ismail, K. M. K., Green, J. S. A., \& Bick, D. (2017). Implementation of guidelines for multidisciplinary team management of pregnancy in women with pre-existing diabetes or cardiac conditions: Results from a UK national survey. BMC Pregnancy and Childbirth, 17(1). https://doi.org/10.1186/s12884-017-1609-9 
Timmermans, Y. E. G., van de Kant, K. D. G., Reijnders, D., Kleijkers, L. M. P., Dompeling, E., Kramer, B. W., Zimmermann, L. J. I., Steegers-Theunissen, R. P. M., Spaanderman, M. E. A., \& Vreugdenhil, A. C. E. (2019). Towards Prepared mums (TOP-mums) for a healthy start, a lifestyle intervention for women with overweight and a child wish: study protocol for a randomised controlled trial in the Netherlands. BMJ Open, 9(11), e030236. https://doi.org/10.1136/bmjopen-2019-030236

Wieser, H., Piccoliori, G., Siller, M., Comploj, E., \& Stummer, H. (2020). Living on the Own Island? Aligned Collaboration Between Family Physicians, Nurses, Dieticians, and Patients With Diabetes Type 2 in an Outpatient Care Setting in Northern Italy: Findings From a Qualitative Study. Global Advances in Health and Medicine, 9, 216495612094670. https://doi.org/10.1177/2164956120946701 